\title{
The Effect of Tax Planning, Ownership Structure, and Deferred Tax Expense on Earning Management
}

\author{
Rina Mudjiyanti \\ Universitas Muhammadiyah Purwokerto \\ rinamudjiyanti@ump.ac.id
}

\begin{abstract}
This research aims to test the effect of tax planning, ownership structure, and deferred tax expense on earnings management. The dependent variable in this research is the earnings management, while its independent variables are tax planning, ownership structures, and deferred tax expense. The population in this research is a manufacturing company in the Indonesia Stock Exchange Period 2013-2016. The sampling in this research is purposive sampling method and it obtained 72 observation samples. The data analysis method used is multiple linear regression analysis methods. The analysis results show that tax planning affects significantly positive and institutional ownership affects significantly negative towards earning management. Meanwhile, managerial ownership and deferred tax expense do not affect significantly towards earning management.
\end{abstract}

Keywords: earnings management, tax planning, managerial ownership, institutional ownership, INTRODUCTION

The financial report is a mean of giving financial information as well as providing information on the financial performance of a company and how the management of a company responsible to the owner [1]. Earnings are one of the main important information in determining the financial reports of a company's performance. Management will determine certain decisions and the policies chosen called as management profit [2]. Companies generally set targets that are shown to potential investors. Companies can increase or decrease income in earning management activities, investors often are not aware of such action so that it is vulnerable to make decisions that are not effectively based on the information that has been manipulated [3].

In this study, the one that affects the earnings management was tax planning. In the agency theory, government as a principal party and as party agent management has different interests in terms of tax payments [4]. Another factor that affect the management of the profit is structure of ownership. In the theory of agency, the greater managerial ownership a manager master stock will have more information than the shareholders, while institutional ownership has important role in the agency conflict between shareholders and managers [5]. Deferred interest is a burden that is to learn the difference of interests which is done by the manager of the principal.

This study is to examine the usefulness of the deferred tax expense as compared to various accrual measures employed in prior research to detect earning management. The motivation using variable deferred tax expense to detect earning management is that there is typically more discretion under generally accepted accounting principles than under tax rules. The assumption that managers exploit such discretion to manage income upwards primarily in ways that do not affect current taxable income. Deferred tax expense is generally incrementally useful beyond all three accruals-based measures with regard to detecting earning management to avoid a loss.

The research objective is projected to obtain empirical evidence whether there is any positive effect of tax planning, positive influence of managerial ownership, negative influence of institutional ownership, and whether there is deferred tax expense burden of positive influence towards earnings management.

Principal delegates decision making authority in the management of the company to the manager of the company. The manager tried to present the financial statement as carefully as one from accountability management toward principal [5].

\section{METHOD}

This research is quantitative, the population is the whole manufacturing company in Indonesia Stock Exchange (BEI) throughout 2013-2016. The sampling method used is purposive sampling. The data collection used was secondary data, quantitative data. In addition, data analysisused in this study is multiple linear regression analysis. The data source obtained from the official website from 2013-2016 period of BEI.

Operational definitions of variables and measurements

a) Earning Management

Earningmanagement can be measured through discreti onary accrual, calculated by means of the total accrual 
(TA) and are classified into Accrual (DA) and nondiscretionary accrual (NDA) [6]. Earning management measured through discretionary accrual using Modified Jones. Model calculations are as follows:

b) Tax Planning

Tax planning as the process of organizing the effort of the taxpayer or taxpayer groups such that the debt taxes either income tax or other taxes are in the positio $\mathrm{n}$ of the minimal possible [7].

c) Managerial Ownership

Managerial ownership is ownership by a manager. This variable using the formula with a percentage amount of the share owned on farm management for the entire amount of the company's share in circulation [6].

\section{d) Institutional Ownership}

Institutional ownership (INST) is the percentage of particular stock that is owned by institutions within a company. Ownership institutional in size with the proportion of shares owned by the institution at the end of the year compared to the number of outstanding shares in the company [8].

e) Deferred Tax Expense

Calculation of deferred tax expense is calculated using the deferred tax expense to see indicators with total assets. This is done for deferred tax expense weighting with total assets at period $t_{1}$ to obtain the computed value with proportional.

\section{RESULTS AND DISCUSSION}

Table 1 describes the sample selection procedure. This sample was taken from manufacturing company listed on the Indonesia Stock Exchange period 2013-2016.

Table 1. Sample

\begin{tabular}{clc}
\hline No & \multicolumn{1}{c}{ Sample Criteria } & $\begin{array}{c}\text { The total numb } \\
\text { er of sample }\end{array}$ \\
\hline 1 & $\begin{array}{l}\text { Total manufacturing companies } \\
\text { listed on the Indonesia stock } \\
\text { exchange period 2013-2016 }\end{array}$ & 130 \\
2 & $\begin{array}{l}\text { The company has no net profit, } \\
\text { managerial and institutional } \\
\text { ownership, period 2013-2016 } \\
\text { (row data) } \\
\text { The number of companies that } \\
\text { meet the criteria } \\
\text { Years of observation } \\
\text { Total samples during the researc } \\
\text { h period }\end{array}$ & 112 \\
\hline
\end{tabular}

\section{Hypothesis Testing}

Be aware that the value of their significance is 0,000 . The significance of value is less than 0,05 . So the regression models can be concluded as declared viable. Be aware that the coefficient of determination $\left(R^{2}\right)$ of 0,065 , this value indicates that the independent variable i.e., tax planning, managerial ownership, institutional ownership, deferred tax expense can explain variation variable of the dependent earnings management for $60,5 \%$ and the remaining $39,5 \%$ which is explained by other variables that have significant effects on earning management.

\section{Multiple Linear Regression Test}

From the results of the linear regression equation can be known compounds that can be formulated in this research are as follows:

$\mathrm{ML}=0,400+0,424$ PP- 0,010KM - 0,011KI $5,107 \mathrm{BPT}+\mathrm{e}$

Interpretations of these equations are as follows:

The regression coefficient of the tax planning has a positive regression coefficient variable 0,0424 , managerial ownership is the regression coefficient variable $-0,010$, variable institutional ownership is the regression coefficient variable 0,011 , and regression coefficients of the variable deferred tax expense are $-5,107$.

Discussion of the first hypothesis test results indicates that the variable tax planning has a positive coefficient value with the value significance of 0.000 (under 0.05 ) which has a positive coefficient value direction. Thus, the first hypothesis states that the variable has positive effect against tax planning management profit earned (received). These results are in line with research $[9,10]$. But the results of this research is different from research [11].

The second hypothesis test, results in the table above indicates that the managerial ownership showed the value of coefficient -0.010 and significant value of 0.169 (above 0.05 ) has a direction coefficient is negative. So the second hypothesis states the positive effect of managerial ownership towards the management are not accepted (rejected). These results are in line with research?. But the results of this research in different to research?.

The third hypothesis test results in the table above indicate that the ownership of the institutional shows the value of the coefficient-value 0.011 and significant of 0.003 (under 0.05 ) has a direction coefficient is negative. Thus, the third hypothesis asserts ownership of institutional effect negatively to earning management is acceptable (accepted). The results of this study are in line with research by Wiryadi dam Sebrina [1]. But the results of this research contrast with research [13].

The fourth hypothesis research results in the table above indicate that the variable load of tax-deferred interest has a coefficient of -5.107 and significant value of 0.185 (above 0.05 ) has a direction coefficient is negative. So the fourth hypothesis which states tax-deferred interest burden of positive effect on profit management was rejected. The result is different from research results [9]. 


\section{CONCLUSION}

Based on the results of research and discussion, it can be concluded that positive effect of tax planning against institutional ownership, profit management affects negatively to earnings management, ownership managerial and deferred tax positively affect not against earnings management. This research suggested in the next research can use different variables, to see if earning management in a company still going through other variables such as quality audit, leverage, and corporate governance.

Add to the research period, namely for 5 years so that the results can be seen by a company to do profit management. When companies have good business performance, the tax burden will be relatively lower, also it weaken the tax-avoidance motivation in earnings management. However, for state-backed companies which are free of restrictions like tax-avoidance risk, they receive benefits from tax avoidance persistently and thus their business performance has little influence on the motivation of earnings management. Hence, for companies do not have a good relationship with government, the taxavoidance motivation gradually reduces with the improvement of the business performance. References [1]. Study at Malaysian PLCs use both the accrual and valuation allowance components of net deferred tax liabilities to avoid a decline in earnings [9].

\section{REFERENCES}

[1] Kamran, K., \& Shah, A. The impact of corporate governance and ownership structure on earnings management practices: Evidence from Listed Companies in Pakistan. The Lahore Journal of Economics Vol 19No. 2,2770. (2014).

[2] S. Wang and S. Chen, "The Motivation for Tax Avoidance in Earnings Management," Int. Conf. Eng. Bus. Manag., 2012.

[3] Jensen, Michael., Meckling, William H. Theory of the firm: Managerial Behavior, Agency Cost, and Ownership Structure. Journal of Financial Economics, Vol 3, No. 4. 1976.
[4] Sari, Septia Puspita. Pengaruh Kepemilikan Instusional, Ukuran Perusahaan, Leverage Dan Kebijakan Dividen Terhadap Manajemen Laba. Jurnal Online Mahasiswa. (2014).

[5] Sumomba, C. R. Pengaruh Beban Pajak Tangguhan dan Perencanaan Pajak Terhadap Manajemen Laba. KINERJA. Vol 16 No. 2. Hal 103-115. (2012).

[6] Kusumawardhani, I. Pengaruh Corporate Governance, Struktur Kepemilikan, Dan Ukuran Perusahaan Terhadap Manajemen Laba. Jurnal Akuntansi dan Sistem Teknologi Informasi Vol, 9 No. 1, Hal 41-54. (2012).

[7] J. Kasipillai and S. Mahenthiran, "Deferred taxes, earnings management, and corporate governance: Malaysian evidence," J. Contemp. Account. Econ., 2013.

[8] Fitriany, L. C. Pengaruh Aset Pajak Tangguhan, Beban Pajak Tangguhan Dan Perencanaan Pajak Terhadap Manajemen Laba. JOM Fekon Vol 3 No. 1. 2016.

[9] F. Aditama and A. Purwaningsih, "Pengaruh Perencanaan Pajak Terhadapa Manajemen Laba Pada Perusahaan Nonmanufaktur Yang Terdaftar Di Bursa Efek Indonesia," J. Akunt., vol. 26, no. 1, pp. 1-15, 2014.

[10] Setiawati, Loh Wenny., \& Lieany. Analisi Pengaruh Perjanjian Utang, Kepemilikan Instusional Dan Ukuran Perusahaan Terhadap Manajemen Laba Rill Pada Perushaan Manufaktur Yang Terdapat Di Bursa Efek Indonesia. Jurnal Akuntansi. Vol 9 No. 2. (2016)

[11] Sibarani, T. J., Hidayat, N., \& Surtikanti, S. Analisis Pengaruh Beban Pajak Tangguhan, Discretionary Accruals, dan Arus Kas Operasi terhadap Manajemen Laba. JRAP (Jurnal Riset Akuntansi dan Perpajakan). Vol 2 No. 1. Hal 19-31. ISSN 2339-1545. (2015). 